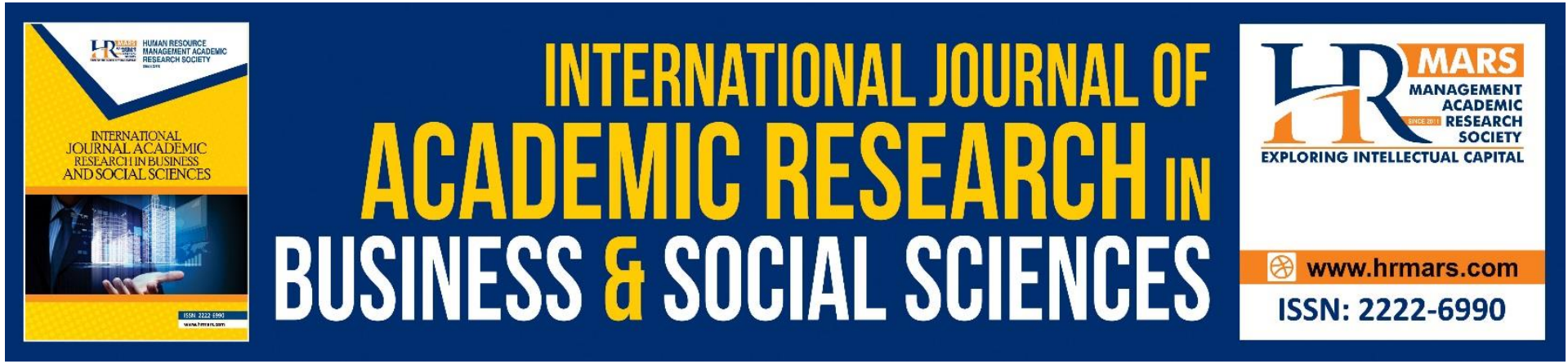

\title{
Participation Malay Women in Entrepreneur
}

Shahrul Hilmi Othman, Mohd Azam Yahya, Noor Jeffry Abdul Wahab, Illy Yanti, Ahmad Nurilakmal Norbit, Nurul Athirah Mohd Azmi

To Link this Article: http://dx.doi.org/10.6007/IJARBSS/v11-i8/10864

DOI:10.6007/IJARBSS/v11-i8/10864

Received: 18 June 2021, Revised: 22 July 2021, Accepted: 12 August 2021

Published Online: 29 August 2021

In-Text Citation: (Othman et al., 2021)

To Cite this Article: Othman, S. H., Yahya, M. A., Wahab, N. J. A., Yanti, I., Norbit, A. N., \& Azmi, N. A. M. (2021). Participation Malay Women in Entrepreneur. International Journal of Academic Research in Business and Social Sciences, 11(8), 1489-1497.

\section{Copyright: @ 2021 The Author(s)}

Published by Human Resource Management Academic Research Society (www.hrmars.com)

This article is published under the Creative Commons Attribution (CC BY 4.0) license. Anyone may reproduce, distribute, translate and create derivative works of this article (for both commercial and non-commercial purposes), subject to full attribution to the original publication and authors. The full terms of this license may be seen at: http://creativecommons.org/licences/by/4.0/legalcode

Vol. 11, No. 8, 2021, Pg. 1489 - 1497

Full Terms \& Conditions of access and use can be found at http://hrmars.com/index.php/pages/detail/publication-ethics 


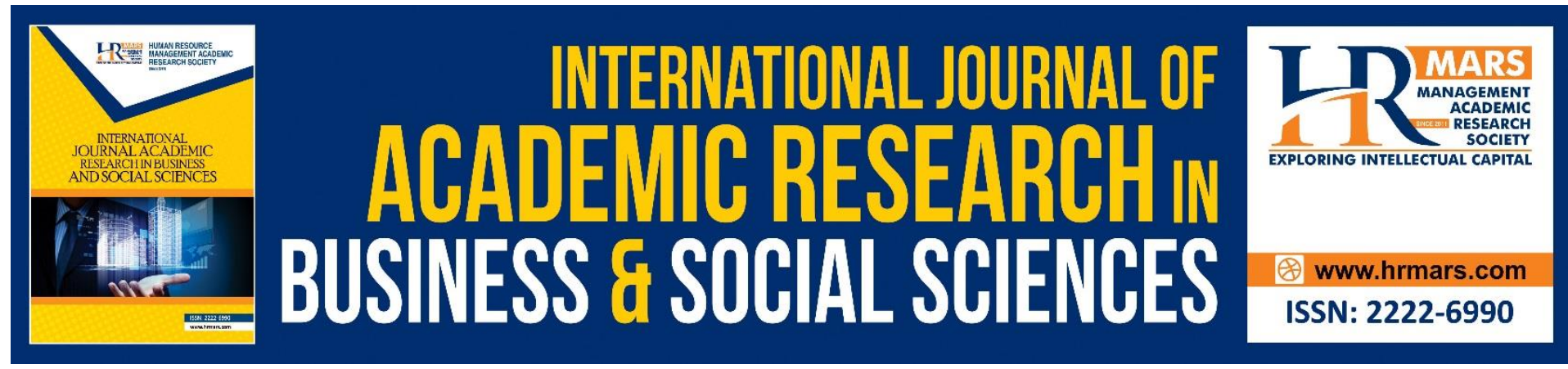

\section{Participation Malay Women in Entrepreneur}

\section{Shahrul Hilmi Othman', Dr Mohd Azam Yahya², Noor Jeffry Abdul Wahab ${ }^{3}$, Illy Yanti ${ }^{4}$, Ahmad Nurilakmal Norbit ${ }^{5}$, Nurul Athirah Mohd Azmi6}

${ }^{1}$ Head of Hajj and Umrah Management Research Institute, University College of Islam Melaka, ${ }^{2}$ Dean of the institute of postgraduate studies, University College of Islam Melaka. ${ }^{3}$ Director of Academic Affair, University College of Islam Melaka, ${ }^{4}$ Lecturer Faculty of Sharia UIN Sultan Thaha Saifuddin Jambi, Indonesia, ${ }^{5}$ Lecturer Faculty of Language and Education, University College of Islam Melaka, ${ }^{6}$ Lecturer Faculty of Islamic Knowledge, University College of Islam Melaka.

Email: shahrul@kuim.edu.my

\section{Abstract}

This article to explain womenpreneurship according to the Islamic Economics, involvement of women in the economy between Malaysia and Indonesia, and the opportunities for Malaysian Women in Entrepreneurship. The discussion of this paper uses a qualitative research methodology approach. The primary method of data collection through library research approach to obtain written documents, ancient Malay manuscripts. Data analysis using historical research approach to look at the source and history of Islamic thought. This study uses the method content analysis and historiography methodologies, data were obtained through documents, books and historical collections. The results of this article found that entrepreneurship is one of the fields that can revive the Muslim economy. This finding makes it clear that the role of women in business has long been practiced especially during the time of the Prophet Muhammad and continues in the Malay world by running businesses such as smart partnerships, money exchange. The findings of this study are has shown that Indonesia is ranked 68th overcoming Malaysia at $97^{\text {th }}$ in Gender Gap Index that is to precede in terms of Legislators, senior officials and managers. When Malaysia is ranked well in the dimensions Labour force participation rate, Wage equality for similar work, Estimated earned income and Professional and technical workers. The types of businesses that women do in Malaysia are food and beverage, clothing and clothing, grocery stores, beauty, jewelry and flowers, sewing, bookstore. Womenpreneurs activities in Malaysia are taken seriously by the government with an entrepreneurial development approach through Motivation, Support and Capital.

Keyword: Islamic Entrepreneurship, Womenpreneur, Gender Gap, Malay Women

\section{Introduction}

The overall gender gap performance is a synthesis of performances across the four dimensions composing the index is Educational Attainment, The Economic Participation, Health and Survival and Political Empowerment sub-indexes. As such it masks significant differences in gender gaps across dimensions. Overall, this year's positive result has been 
driven mainly by a progress on the Political Empowerment sub index, as well as by marginal improvements on the Health and Survival and Educational Attainment sub index. Conversely, the progress towards gender parity in terms of Economic Participation and Opportunity registers a retraction. The second dimension where the gender gap is widest globally is the one measured by the Economic Participation and Opportunity sub index. Here, only $58 \%$ of the gap has been closed so far, and it has slightly widened since last year. The dispersion between the best performing countries and those at the bottom of the ranking is substantial. While the top 10 countries have closed at least $80 \%$ of the gap, the bottom 10 countries have only closed $40 \%$ of the gap between men and women in the workplace (Global Gender Gap Report 2020). This study will describe the opportunities and inclusion of women in the economy that is focused on entrepreneurship according to the perspective of Islamic economics.

\section{Research Methods}

The Objectives of the study are:

$>$ Describes womenpreneurship according to the Islamic Economics

$>$ Explain the involvement of women in the economy between Malaysia and Indonesia

$>$ Describes the opportunities for Malaysian Women in Entrepreneurship

The discussion of this paper uses a qualitative research methodology approach. The primary method of data collection through library research approach to obtain written documents, ancient Malay manuscripts obtained from the National Library of Malaysia. Data analysis using historical research approach to look at the source and history of Islamic thought, especially with regard to women and entrepreneurship in the Malay world.

\section{Finding}

\section{Womenpreneur in Islamic Economics}

Islam is a way of life. Islamic lifestyle refers to a lifestyle that is in line with Islamic teachings. Islam is not only about faith in the heart, but also needs to be practiced and displayed with noble character and personality. Islam requires its adherents to have the right faith, carry out the practices required by Islam and show noble character to get the blessings of lawful sustenance. The study of entrepreneurship which was first discussed and developed in the Western scientific tradition dates back to the 18th century from the Cantillon era who is said to have pioneered the term entrepreneurship. The famous Islamic sociologist Ibn Khaldun (1967) mentions that Tijārah (التجارة) in the context of his writings is a trade which means an effort to earn profits by increasing capital, by buying goods at low prices and sell it at a high price, trading transactions are well done either waiting for price fluctuations in the market or moving it to another place that needs it more and getting a higher price.

Al-Qaradawi (2001) in discussing the issue of values and morals in Islamic economics by saying that entrepreneurship as a form of worship through economic activities in various sectors (production and services), which is beneficial for humans to improve the standard or necessities of life. life becomes more perfect and prosperous according to the divine balance. Meanwhile, Al-Syaibani (2004) defines business as the exchange of money for goods or goods for goods for profit. Meanwhile, one of the contemporary Islamic economic figures, Siddiqi (1979) defines entrepreneurship as "a person who has the skills and abilities to combine various factors of production needed to generate needs. Entrepreneurs also run the risk of 
failing to meet expectations due to market demands. They try to earn income for a good life through business ventures and by this endeavor they also contribute to society".

Entrepreneurship and business are indeed required in Islam to fulfill human nature in owning property, with these assets humans can meet the needs and desires of individuals, families, communities and countries. In addition, wealth can also bring people to the good of the world and the hereafter as long as the treasure is obtained and spent in accordance with Islamic law, including the Prophet Muhammad SAW who became a trader along the Arabian Peninsula with another Arab caravan, Prophet Muhammad has proven that entrepreneurship is a strategic career that must be undertaken by Muslims as a whole. Since then, the glory of Islam has been sustained by business groups consisting of friends and tabi'in. The Companions have proven that business is the main source of driving the Muslim economy. In fact they have shown that they are more caliber in this field than other races including Jews. The business that was carried out at that time was more transparent and far from fraud problems. Most entrepreneurs are called traders and traders are entrepreneurs (Bardai, 2000), so Islam hates unemployment and the demands of life (Taleqani, 1983).

Islam has abolished discrimination against women. In historical records, Islam descended in the midst of the Jahiliyah society, a society that demeaned the dignity of women. Islam came, then stipulates several laws to elevate the dignity of women; formulating how to become a woman according to her nature, so that the social inequality that occurred at that time became balanced (Subhan, 1999). Women have similarities with men spiritually, morally and intellectually. Islam does not prohibit women from working, let alone entrepreneurship. Even the wife of the Prophet Muhammad himself was a wealthy merchant. His business activities crossed national borders to the international level. Islam does not forbid women from engaging in business, Muslim women need to keep their boundaries as Muslim women, let alone assume the responsibilities of mother and wife. Azmi (2014) explains that among the things that need to be considered by Muslim entrepreneurs is ensuring that the goods sold are halal and not haram or syubhah and free from immoral activities such as prostitution and alcohol.

\section{The Involvement of Women in The Economy Between Malaysia And Indonesia}

Islam first entered the Malay world ${ }^{1}$ at the end of the 8th century AD in the first Islamic kingdom, namely Peurlak, in the history of Islamization of the Malay world, trade is one theory

\footnotetext{
${ }^{1}$ Malay world will be explained from the aspect of language, geography and culture, Malay World refers to the geographical aspect which covers the area from Madagascar to Tanah Melayu, Papua New Guinea, Australia, New Zealand, Pacific Islands and up to Taiwan (Nik Hassan Shuhaimi Nik Abdul Rahman, 2016), while Alfred Russel Wallace (2009) explained that the Malay World covers the Malay Archipelago to Tenasserim and the Solomon Islands to Papua New Guinea". Asmah Haji Omar (2008) explains Malay World from the aspect of language or Lingua franca "The cognate languages in Malay World are related to the native ethnic languages. This similarity can be known for sure through certain words. When comparing these cognate languages, there is a familial relationship between these languages and Malay. The use of the Malay language has been widely used in the Malay world since its inception. The nature of the Malays who like to sail has developed the Malay language again into the Malay world. In addition, the nature of Malay language, which is simple and easy to learn, allows this language to be accepted in the Malay world (Sutan Takdir Alisjahbana, 2008). While the cultural aspect according to A. Aziz Deraman (2005) explains that the culture in Malay World has developed forward with the emergence of certain skills in the arts, including gangsa making and the art of self-defense. Both of these skills are original creations in the Malay world. In addition, cognate values exist in the Malay World community,
} 
that is generally associated with the question of how Islam can be introduced and propagated. to Malay (Hamid, 1982). This means that traders, for example from Arab origin, played a role when dealing with trade and business-oriented ports, being the first spreaders of Islam to the region (Archer, 1938). One of the most famous ports in the Malay world in the 15th century was located in Barus Harbor on the west coast of Sumatra which was famous for its gold trade with the Indians (Dasgupta, 1962). In addition, Barus became a port of entrepot by offering special commodities which were seized by traders from India, China and Arabia, the main commodity of Barus was Camphor. Besides being the center of trade traffic and Barus was also the idea of the spread of Islam in the Malay world. The entry of Islam to Barus apparently preceded the time when Aceh accepted Islam, there was a group of Muslims from Persia, Arabia and India who settled in Barus, Singkil to trade while waiting for the change of seasons, through trade and marriage with the local community. Islam is widespread. The Aceh government was one of the great Islamic powers that was very influential in the 16th century BC equivalent to Morocco, Turkey, Isfahan, Agra and Aceh Dar al-Salam (Smith, 1957), This attracted the interest of foreign traders who visited the port of entrepot Banda Aceh.

The success of Islam in the Malay world has left its mark on the development of women in various aspects such as the female-led government of the Aceh kingdom, in the golden age of Aceh's government has existed brokers and money changers who were pioneered by women both in the market and in ports in Banda Aceh, currency exchange activities involving the conversion of gold (known as mas). with tin currency (called Cash) (Denny Lombard, 1991), and at that time there were 500 money changers on a street in Pedir which were run by women, this is a fact that shows the existence of large trade transactions (Dasgupta, 1962).

In the 16th century government Aceh was ruled by women during the period 16411699, the era series began in Sultanah Tajul Alam Syah Sufiatuddin Syah Sovereign (1647-1675 AD), he became the first of four queens or sultans, Sultanah Tajul Safiatuddin-Alam Syah (1612-23 October 1675) was the fourteenth ruler of Aceh. She was the daughter of the sultan Iskandar Muda and the wife of his successor, Iskandar Thani. She became sulțāna upon the death of her husband and ruled from 1641 to 1675, being the first of four women to hold the position in succession. In spite of these political setbacks, Taj ul-Alam was praised by both indigenous and European writers (Andaya, 2004). The chronicle Bustanus Salatin characterized her as virtuous and pious, implying that her qualities made Aceh peaceful and prosperous. Likewise a Dutch witness asserted that she led a "good-natured but awe-inspiring" rule (Khan, Sher Banu, 2010).

Aceh's economy and trade at the time of recording experienced rapid development. The source explained that the port of Aceh is always crowded with the arrival of many foreign merchant ships. In addition, during Safiatuddin, food prices fell and the Aceh Government enjoyed prosperity. The trading elephants in Aceh were also squirming at the time of recording. Between 1628 and 1635, about 62 elephants were exported from Aaceh to Bengal and Masulipatnam. In 1641, the number of elephants exported from Aceh to Masulipatnam, Bengal, Orissa, and Coromandel was recorded at 32. In 1644, Shah Shuja (son of the Mughal emperor Shah Jahan) was sent to Aceh to buy 125 elephants. Although the number of elephants sold to India each year varied from 2 to 32 in the period 1641 to 1662, in 1663 the number reached 43. It is recorded that he was aggressively protective of Aceh's elephant

especially mutual cooperation. In the aspect of performing arts, shadow puppets appeared in Kelantan and Java. Malay World is also known as Nusantara or Alam Jawi or Malay Archipelago. 
commodities and succeeded in protecting Aceh's elephants from being prompted by requests for concessions The Dutch East Indies Company (Verenigde Oostindische Compagnie), gold in large quantities was found during Safiatuddin's time, thus increasing state revenue (Khan, 2017). In the late 17th century, gold became the main attraction of Aceh's ports (Dasgupta, 1962). Safiatudin Sultanah Nur had led the mufti of the Aceh government at that time, Sheikh Abdul Rauf Singkil, who was a well-known cleric in Islamic law to compile a book of Islamic law in the business sector to serve as a reference for judges under the Aceh government.

But now, the Gender Gap 2020 report in the Economic Participation and Opportunity sub-index, has shown that Indonesia is ranked 68th overcoming Malaysia at 97th. The comparison of dimensions under the Economic Participation and Opportunity sub-index is as follows.

\begin{tabular}{|c|c|c|c|c|c|c|}
\hline \multirow{2}{*}{$\begin{array}{l}\text { Economic participation and } \\
\text { opportunity }\end{array}$} & \multicolumn{3}{|c|}{ MALAYSIA } & \multicolumn{3}{|c|}{ INDONESIA } \\
\hline & Ranking & Score & Note & Ranking & Score & Note \\
\hline $\begin{array}{l}\text { Labour force participation } \\
\text { rate, } \%\end{array}$ & 107 & 0.681 & $\begin{array}{l}\text { Male: } \\
80.8 \% \\
\text { Female: } \\
55 \%\end{array}$ & 115 & 0.647 & $\begin{array}{l}\text { Male : } \\
83.9 \% \\
\text { Female: } \\
54.3 \%\end{array}$ \\
\hline $\begin{array}{l}\text { Wage equality for similar } \\
\text { work, } 1-7 \text { (best }\end{array}$ & 20 & 0.744 & - & 51 & 0.693 & - \\
\hline $\begin{array}{l}\text { Estimated earned income, } \\
\text { int'l } \$ 1,000\end{array}$ & 71 & 0.623 & - & 116 & 0.505 & - \\
\hline $\begin{array}{l}\text { Legislators, senior officials } \\
\text { and managers, \% }\end{array}$ & 116 & 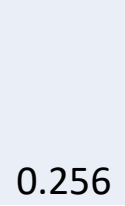 & $\begin{array}{l}\text { Male: } \\
20.4 \% \\
\text { Female: } \\
79.6 \%\end{array}$ & 1 & 1.00 & $\begin{array}{l}\text { Male : } \\
45.1 \% \\
\text { Female: } \\
55.00 \%\end{array}$ \\
\hline $\begin{array}{l}\text { Professional and technical } \\
\text { workers, \% }\end{array}$ & 101 & 0.799 & $\begin{array}{l}\text { Male: } \\
55.6 \% \\
\text { Female: } \\
44.4 \%\end{array}$ & 112 & 0.669 & $\begin{array}{l}\text { Male: } 59.9 \% \\
\text { Female: } \\
40.1 \%\end{array}$ \\
\hline
\end{tabular}

\section{Womenpreneur in Malaysia}

The gender gap in the world of entrepreneurship that is felt in developed countries as written in the research paper explains that gender is still an obstacle for some women to start a business because women still doubt their ability to have their own business (Thebaud, 2010). Women have been active in entrepreneurship for a long time. Among the factors driving women to engage in male-dominated fields are the desire to increase income and freedom and economic demands to continue living, Types of Business Conducted by Women in Malaysia are food and beverage, cloth and clothing, grocery stores, beauty, jewelry and flowers, Tailoring, bookstores (Thuaibah, et al., 2007). Women who are in business carry various roles that enable them to optimize the industry and economic development of the country. Among these roles are (1) a source of money and financial stability, (2) preserving ancestral culture and maintaining family dignity, and (3) creating jobs (Abdullah, et.al., 1992). Women-owned businesses account for 20.6 percent of the total small and medium enterprises (SMEs) in Malaysia and contribute RM69.1 billion to the country's Gross Domestic 
Product (GDP) and create 786,132 jobs. The number of women's businesses has increased by 44 percent since 2011 according to the 2016 Economic Census.

Based on the findings of the Malaysian Gender Gap Index (MGGI), findings from the World Economy Forum on GGGI identify gaps between women and men in four sub-indices, namely Economic Opportunity and Participation, Educational Achievement, Health and Life Political Dominance. The score with a value of 1.0 (100\%) indicates that the gap between women and men has not been achieved. Furthermore, the activities of womenpreneurs in Malaysia are taken seriously by the government with an entrepreneurial development approach through Motivation, Support and Capital. All of this assistance is handled through several ministries and institutions, namely the Ministry of Village and Regional Development, the Ministry of Women's Empowerment, Family and Community. The Ministry of Enterprise and Cooperative Development, the People's Trustee Council (MARA), Amanah Ikhtiar Malaysia (AIM), the Economic Savings Association of Commerce Business Group (TEKUN) and the SME Bank. In addition, one of the government's efforts to increase womenprenuers is also to hold a capacity building program through business matching- Mentoring-coachingadvisory services that have been implemented by the National Entrepreneurship Institute (Insken) including Insken BizLife-Women, Insken Women Entrepreneur Biz Coaching and Insken Women. Champions. The National Persevering Women Care Program, SKM (Women's Cooperative Strengthening Program), Bank Rakyat (Biz Cares Lady) and UDA Holdings Berhad (UDA BizzNita-FinCare namely Micro Finance (UDA Malls).

\section{Conslusion}

There are various steps that can be proposed to encourage women to enter business and reduce the limitations of existing roles to enable women to adapt their roles more effectively. To date, the government has introduced various policies aimed at encouraging women to expand their business ventures. The government has also provided initiatives in the form of financial assistance to women who are interested in exploring rapidly growing business opportunities. To achieve this goal, several recommendations to strengthen and optimize the role of women will be achieved through the following recommendations:

1. Product innovation by creating new high quality products. Women entrepreneurs must be brave and ready to be creative and innovative and take advantage of them. Innovation is very important for every business be it products or services and it depends on the type of business being run. Women entrepreneurs always need to have an effort towards product innovation, to meet the needs of their customers.

2. Women entrepreneurs must always maintain good relations with suppliers, customers, government officials, intermediaries, banks and so on. For women entrepreneurs who are just starting a business, it is always necessary to establish good relations with related parties.

3. Special training programs in the field of entrepreneurship should be carried out systematically in preparation for women to advance themselves and seize opportunities in business. Such specialized training should be conducted to expose women to start-up capital, consulting and training services such as product processing as well as leadership and motivational courses to increase knowledge while running a business.

4. Financial assistance facilities. The business sector requires sufficient initial capital to start. Along with that, assistance in terms of capital needed by women to run a 
business must be facilitated. This is in line with the government's desire to empower women who are involved in business while helping them as an economic resource.

\section{References}

Abdullah, W. M., Hamid, A. H., \& Nawawi, H. (1992). Penglibatan wanita dalam pembangunan luar bandar: Kajian kes industri desa di Kelantan. In T. King, V. \& Mat Jali, N. Isu-isu pembangunan luar bandar di Malaysia (p. 455-465). Kuala Lumpur: Dewan Bahasa dan Pustaka.

Al-Attas, S. F. (1985). Notes on Various Theories Regarding the Islamization of the Malay Archipelago, The Muslim World, 75(3-4), 162-175.

Alisjahbana, S. T. (2008) Indonesia: Social and Cultural Revolution, Jakarta: Dian Rakyat.

Al-Qaraḍawi, Y. (2001). Dawr al-Qiyām wa al-Akhlāq fï al-lqtișād al-Islāmī. Kaherah: Maktabah Wahbah.

Al-Syaibani, M. (2004). Al-lqna. Bayrut: Dar Kutob al-Alamiyah.

Ambary, H. M., \& Burhanuddin, J. (1998). Menemukan peradaban : jejak arkeologis dan Historis Islam Indonesia. Ciputat: Logos Wacana Ilmu.

Andaya, L. Y. (2004). 'A Very Good-Natured but Awe-Inspiring Government: The Reign of a Successful Queen in Seventeenth-Century Aceh' in Elsbeth Locher-Scholten and Peter Rietbergen (ed.), Hof en handel. Leiden: KITLV Press, 59-84.

Archer, R. L. (1938). Muhammadan Mysticism in Sumatra, The Muslim World, 28(3), 31.

Arnold, T. W. (1999). The Preaching of Islam: A History of the Propagation of the Muslim Faith, edisi kedua, New Delhi: Kitab Bhavan.

Azmi, I. A. G. (2014). The Implementation of Islamic Business Practices of Women Traders: A Study in an Islamic State in a Developing Country, Global Journal Al-Thaqafah, 4 (2), 17- 28.

Azra, A. (1998) Jaringan Ulama Timur Tengah dan Kepulauan Nusantara Abad XVII dan XVIII: Melacak Akar-Akar Pembaruan Pemikiran Islam di Indonesia, cetakan keempat, Bandung: Penerbit Mizan.

Bardai, B. (2000). Keusahawanan dan perniagaan. Kuala Lumpur: Dewan Bahasa dan Pustaka.

Dasgupta, A. K. (1962). Aceh in Indonesian Trade and Politics: 1600-1641. Ph.D Disertation. School of Postgraduate, Universiti Cornell.

Deraman, A. A. (2005). Masyarakat dan Kebudayaan Malaysia. Kuala Lumpur: Dewan Bahasa dan Pustaka.

Djajadiningrat, R. H. (1911) 'Critisch overzicht van de in Maleische werken vervatte gegevens over de geschiedenis van het soeltanaat van Atjeh', Bijdragen tot de Taal-, Land- en Volkenkunde. 65, 135-265.

World Economic Forum. (2021). Global Gap Index Report 2020. World Economic Forum. Switzerland.

Haron, S. (1990). Ke Arah Menjadi Usahawan Yang Berjaya. Kuala Lumpur: Dewan Bahasa dan Pustaka,

Ibnu Khaldūn, A. A. R. (1967). Muqaddimah Ibnu Khaldūn. Jil.3. Kaherah: Maktabah Dār alTurāth.

Khan, S. (2010). 1. The Sultanahs of Aceh, 1641-99. In A. Graf, S. Schroter \& E. Wieringa (Ed.), Aceh: History, Politics and Culture (pp. 3-25). Singapore: ISEAS Publishing. https://doi.org/10.1355/9789814279130-004

Khan, S. (2017). Sovereign Women in a Muslim Kingdom: The Sultanahs of Aceh, 1641-1699. Singapore: NUS Press. 
Lombard, D. (2006), Kerajaan Aceh zaman Sultan Iskandar Muda (1607-1636), Kepustakaan Populer Gramedia : Forum Jakartas-Paris : Ecole francaise d'Extreme-Orient

Lombard, D. (1991) Kerajaan Aceh Jaman Sultan Iskandar Muda (1607-1636), Jakarta: Balai Pustaka.

Meuraxa. D. (1973). Sejarah masuknya Islam ke bandar Barus, Sumatera Utara; Lobu Tuo, Fansur Barus lebih dahulu dari Sriwijaya, Lemuri, Perlak, Pasai dan Majapahit. Medan: Penerbit Sasterawan.

Omar, A. (2008). Ensiklopedia Bahasa Melayu, Kuala Lumpur: Dewan Bahasa dan Pustaka.

Ricklefs, M. C. (1994). A History of Modern Indonesia Since c. 1300, 2nd ed. Stanford: Stanford University Press, pp. 35-36, 51.

Siddiqi, M. N. (1979). The Economics Enterprise In Islam. New Delhi: Markazi Maktaba Islami. Smith, W. C. (1957). Islam and Modern History. Princeton: Princeton University Press.

Subhan, Z. (1999). Tafsir Kebencian; Studi Bias Gender dalam Tafsir Qur'an, Yogyakarta: LKiS. Syamsu, H. M. (1996), Ulama pembawa Islam di Indonesia dan sekitarnya, Jakarta: Lentera.

Taleqani, S. M. (1983). Islam and Ownership. Lexington: Mazda Publisher.

Thébaud, S. (2010). Gender and Entrepreneurship as a Career Choice: Do Self-assessments of Ability Matter?. Social Psychology Quarterly OnlineFirst, 20(10), 1-17.

Thuaibah, A. B., Azlah, M. A., Hishamuddin, M. S., \& Syaharaizatul, N. M. (2007). Penglibatan kaum wanita dalam aktiviti keusahawanan di Negeri Johor: Kajian terhadap faktorfaktor kritikal kejayaan dan kegagalan pengendalian perniagaan. Research Report. Universiti Teknologi Malaysia.

Wallace, A. R. (2009). The Malay Archipelago, Oxford: John Beaufoy Publication.

Zaharah, S., Shuhaimi, N. H., Abdul Rahman, N., and Wan Hashim, W. T. (2016). Sejarah Tamadun Alam Melayu : asal usul melayu, induknya di Benua Sunda. Perak: Penerbit Universiti Pendidikan Sultan Idris. 